\title{
Francesco Casula, Honoré de Balzac (1799-1850)
}

\section{Marco Stupazzoni}

\section{(2) OpenEdition}

\section{Journals}

\section{Edizione digitale}

URL: http://journals.openedition.org/studifrancesi/4404

DOI: $10.4000 /$ studifrancesi.4404

ISSN: 2427-5856

\section{Editore}

Rosenberg \& Sellier

\section{Edizione cartacea}

Data di pubblicazione: 1 settembre 2016

Paginazione: 344

ISSN: 0039-2944

\section{Notizia bibliografica digitale}

Marco Stupazzoni, «Francesco Casula, Honoré de Balzac (1799-1850)», Studi Francesi [Online], 179 (LX | II) | 2016, online dal 01 septembre 2016, consultato il 18 septembre 2020. URL : http:// journals.openedition.org/studifrancesi/4404; DOI : https://doi.org/10.4000/studifrancesi.4404

Questo documento è stato generato automaticamente il 18 settembre 2020.

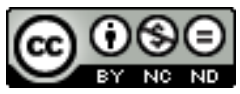

Studi Francesi è distribuita con Licenza Creative Commons Attribuzione - Non commerciale - Non opere derivate 4.0 Internazionale. 


\title{
Francesco Casula, Honoré de Balzac (1799-1850)
}

\author{
Marco Stupazzoni
}

\section{NOTIZIA}

FRANCESCO CASULA, Honoré de Balzac (1799-1850), in I Viaggiatori italiani e stranieri in

Sardegna, Quartu S. Elena, Alfa Editrice, 2015, «Documenti dell'identità», pp. 81-87.

1 Tra le più cocenti e inaspettate disillusioni che costellarono il tormentato percorso delle vicende biografiche (e finanziarie) dello scrittore francese, si annovera, senza dubbio, quella che vide protagonista Balzac in Sardegna nel marzo 1838. Ampia e variegata è la letteratura critica che, in momenti diversi, ma pressoché costantemente dall'Ottocento a oggi - si è occupata delle esperienze di viaggio di Balzac in Italia con un particolare interesse per l'esperienza sarda. La storia del fallimento legato al progetto di sfruttamento di giacimenti di scorie argentifere nell'Isola è noto ed è contenuta nelle sette lettere che lo scrittore indirizzò a Mme Hanska tra il 26 marzo ed il 22 aprile 1838.

2 Alla luce di questa corrispondenza e di altre preziose testimonianze critiche, F. Casula compone un breve ma incisivo quadro della storia e del significato (anche letterario) di questa illusion perdue, di questa improvvida impresa in terra sarda: un luogo selvaggio, scrive Balzac, che si presenta agli occhi del romanziere come l'anticamera geografica e antropologica dell'Africa, ma che Balzac dipinge come fosse un'esotica fantasticheria degna di una vera e propria invenzione da romanzo. 